\title{
Tannins in mangrove plants in Segara Anakan Lagoon, Central Java, Indonesia
}

\author{
ENDANG HILMI ${ }^{1,2, \bullet}$, LILIK KARTIKA SARI ${ }^{1}$, ASRUL SAHRI SIREGAR ${ }^{1}$, ISDY SULISTYO ${ }^{1,2}$, \\ ARIF MAHDIANA ${ }^{1}$, TEUKU JUNAIDI ${ }^{1}$, MUSLIH ${ }^{1}$, RIKA PRIHATI CAHYANING PERTIWI ${ }^{1}$, \\ SESILIA RANI SAMUDRA ${ }^{1}$, NORMAN ARIE PRAYOGO ${ }^{1,2}$ \\ ${ }^{1}$ Program of Aquatic Resources Management, Faculty of Fisheries and Marine Sciences, Universitas Jenderal Soedirman. Jl. Dr Soeparno, Purwokerto \\ Utara, Banyumas 53122, Central Java, Indonesia. Tel.: +62-281-6596700, `email: dr.endanghilmi@gmail.com \\ ${ }^{2}$ Aquatic Resources Graduate Program, Faculty of Fisheries and Marine Sciences, Universitas Jenderal Soedirman. Jl. Dr Soeparno, Purwokerto Utara, \\ Banyumas 53122, Central Java, Indonesia
}

Manuscript received: 28 June 2021. Revision accepted: 28 July 2021.

\begin{abstract}
Hilmi E, Sari LK, Siregar AS, Sulistyo I, Mahdiana A, Junaedi T, Muslih, Pertiwi RPC, Samudra SR, Prayogo NA. 2021. Tannins in mangrove plants in Segara Anakan Lagoon, Central Java, Indonesia. Biodiversitas 22: 3508-3516. Mangrove tannin is polyphenol compound and extractive matter in mangrove vegetation. Mangrove tannins have the potentials to support paint industry, animal feed, tanners and wood adhesives industry. This research is aimed to investigate the mangrove species in Segara Anakan, Central Java, Indonesia that produce tannins, and to analyze the distribution and contents of tannin in the part of mangrove plant. A total of 342 samples from 19 mangrove species was collected from 37 sampling points in Segara Anakan. UV-Visible Spectrophotometry was used to analyze the tannin content in the samples. The results showed that the tannins contained in bark and stems were higher $(66.6 \%)$ than those in leaves (33.4\%). Mangrove vegetation can be classified into five classes in terms of tannin percentage with Heritiera littoralis, Nypa fruticans, and Rhizophora mucronata had highest tannin percentage. The clustering analysis of mangrove tannin showed that Ceriops decandra-Ceriops tagal, Acacia auriculiformis-Sonneratia alba, Sonneratia caseolaris-Xylocarpus granatum, and Avicennia marina-Rhizophora apiculata had high similarity of tannin percentage. The distribution of tannins in mangrove species is as follow: $0.59-10.14 \mathrm{~kg} \mathrm{trees}^{-1}$ (bark and stem of mangrove diameter $>10 \mathrm{~cm}$ ) and $0.20-3.74 \mathrm{~kg}_{\text {trees }}^{-1}$ (leaves of mangrove diameter $>10 \mathrm{~cm}$ ) until 8.84-158.96 kg trees ${ }^{-1}$ (bark and stem of mangrove diameter $>40 \mathrm{~cm}$ ) and 4.60-91.65 kg trees ${ }^{-1}$ (leaves of mangrove diameter $>40$ $\mathrm{cm})$. R. mucronata and $R$. apiculata had the highest total tannin content, ranged between $386.60-460.38 \mathrm{~kg}^{-1}$ trees $^{-1}$.
\end{abstract}

Keywords: Clustering, distribution, mangrove tannin

\section{INTRODUCTION}

Mangrove is vegetation of intertidal zones between marine and terrestrial ecosystems (Bellotti et al. 2012; Rahim et al. 2008; Wang et al. 2018; Yang et al. 2018) has many ecosystem services such as carbon sequestration (Hilmi et al. 2017; Hilmi et al. 2019b), reducing coastal disasters (Hilmi 2018; Suhendra et al. 2018), water conservation, pollution reduction (Hilmi, Sari, and Setijanto, 2019; Hilmi et al. 2017; Sari et al. 2016; Su et al. 2012; Syakti et al. 2013a,b), bioremediation (Hidayati et al. 2011; Syakti et al. 2013a) and provide tannin as non-timber forest product. As the non-timber services, tannin has an important value similar with function to reduce coastal disaster (Hilmi 2018), heavy metal pollution (Syakti et al. 2013a; Hilmi et al. 2017), support REDD program (Hilmi et al. 2017) and activity of conservation and economic carbons (Canu et al. 2015; Avelar et al. 2017; Hilmi et al. 2017; Hilmi et al. 2019). Tannin is a water-soluble substance and extractive matter which is arranged by an aggregation of complex organic compounds (Tahir et al. 2019) and secondary metabolites, such as hydroxyl groups, which are made up of benzene rings, acid classes, and organic sugars (Martins et al. 2020). Tannin also has strong aqueous solution properties (Tahir et al. 2019), which are possibly degraded by the Tannase enzyme. Because of its toxic substances, tannin may act as a pathogen for other plants (Sharma 2019). Tannin also has correlation with the ability of plant protection, production of plants' secondary metabolites and defensive molecules, barriers against the phytopathogen invasions (El-Ashmawy et al. 2016; Sharma 2019; Martins et al. 2020), to protect plants against insects, pathogens, and herbivore animals regarding their defense activities (Sharma 2019). The other functions, tannins are also used to produce adsorbents of heavy metal ions (Martins et al. 2020; Matsutani and Nagai 2013; Oo et al. 2009), to produce tannase enzymes used to adsorb copper, lead, and other industrial products ( Rahim et al. 2008; Oo et al. 2009; Zhang and Li 2017).

Basically, tannin produced by mangroves is classified into hydrolyzed and condensed tannins. Diluted acid concentrations heat hydrolyzed tannins to produce gallic and ellagic acids and more mixtures (Negri and Tabach 2013), while the condensed tannins are polymerized to deliver water-insoluble phlobaphene (Martins et al. 2020; Tahir et al. 2019). However, condensed tannin is also defined as flavonoid polymers and oligomers (Pan et al. 2019). Tannin is also divided into polyphenols, nontannins, and flavonoids (El-Ashmawy et al. 2016; Jinhui et al. 2019; Pan et al. 2019). Also, it is used to assess 
antioxidant and antimicrobial activities (Medini et al. 2014; Zhang and Li 2017). Tannin extracted from mangrove is used to produce phloroglucinol nucleophiles, polar solvents, aqueous acetone and ethanol, water (Tan and Kassim 2011), phenolic resin (Hernes et al. 2001; Antoine et al. 2004; Lei et al. 2019; Pan et al. 2019; Liu et al. 2020), and phytopathogen (Erickson et al. 2012; Sharma 2019).

In mangroves, tannins are produced by many species, such as Caesalpinia spinosa (Bellotti et al. 2012), Rhizophora apiculata (Oo et al. 2009; Rahim et al. 2008a), Rhizophora mucronata (Tahir et al. 2019), Hibiscus rosasinensis and Senna bicapsularis (Mak et al. 2013), and Kandelia obovata (Zhou et al. 2012). The tannins in mangrove are extracted from wasted barks (Oo et al. 2009), bark extracts (Tahir et al. 2019), leaves (Hernes et al. 2001), root and skin (Rahim et al. 2008a; Rahim et al. 2008), and other parts of plant (Mostafa et al. 2018), with concentrations between $107.39 \mathrm{mg} / \mathrm{g}-157.57 \mathrm{mg} / \mathrm{g}$, (Anadenanthera colubrina) and $68.96 \mathrm{mg} / \mathrm{g}-76.55 \mathrm{mg} / \mathrm{g}$ (Lafoensia replicata) (Monteiro et al. 2014).

This research is aimed to investigate the mangrove species in Segara Anakan, Central Java, Indonesia that produce tannins, and to analyze the distribution and contents of tannin in the part of mangrove plant. While there are several studies on a similar topic, this research adds a new context of study area, i.e., Segara Anakan which is recognized as an important mangrove ecosystem remaining in Java Island.

\section{MATERIALS AND METHODS}

\section{Study area}

This research was conducted in Segara Anakan Lagoon, Cilacap District, Central Java, Indonesia (Figure 1). The Lagoon is influenced by the existence of several rivers including Donan, Sapuregel, Kembang Kuning, Citanduy, Cimeneng, and Cikonde (Hilmi et al. 2017; Sari et al. 2016).
The data were collected from 37 sampling site points (Hilmi et al. 2019) (Table 1, Figure 1). The research stations in West Segara Anakan were Sungai Ujung Gagak, Sungai Lorogan, Sungai Majingklak, Sungai Mauara Cawitali, Sungai Kebuyutan, Sungai Batu Macan, Sungai Jongor, Sungai Muara Legok, Sungai Kayu Mati, Sungai Langkap, Sungai Karang Braja, Sungai Klaces, Sungai Inti Ujung Gagak, Sungai Muara Bagian, Sungai Muara Masigitsela, Sungai Pertigaan Ujung Alang, Sungai Ujung Alang, Sungai Dermaga Ujung Alang, Sungai Kali Semak, Sungai Pertigaan Sudiro. While the research stations in East Segara Anakan were Kali Panas 1, Kali Panas 2, Kali Panas 3, Kali Panas 4, Kali Panas 5, Donan 1, Donan 2, Donan 3, Donan 4, Donan 5, Donan 6 (Sleko), Pelawangan Timur, Sapuregel 1, Sapuregel 2, Sapuregel 3, Kembang Kuning 1, and Kembang Kuning 2.

\section{Samples collection procedure}

Data collection was conducted through two stages: (i) Vegetation samples. Vegetation samples from mangrove stems, barks, and leaves were collected and stored in plastic materials used to extract and analyze the percent and weight of tannins (Rahim et al. 2008; Abdullah and Lee 2017; Hilmi et al. 2017). After the collection, vegetation samples were sliced in tiny proportions to ease the process of extraction. In the Segara Anakan Lagoon, the mangrove samples were collected from 19 dominant species with three replicates of each species and three replicates of stems, barks, and leaves (totaling 342 samples). (ii) Sample extraction. Sample extraction was conducted by the maceration method. As many as $700 \mathrm{~g}$ of mangrove powder in the macerator was added with $2 \mathrm{~L}$ of $70 \%$ ethanol for 24 hours and then evaporated using a rotary evaporator. While $10 \mathrm{~g}$ of leaves were blended with $25 \mathrm{~mL}$ of $70 \%$ ethanol, filtered with $25 \mathrm{ml}$ of measuring liquid, and further added with $70 \% \quad \mathrm{C}_{2} \mathrm{H}_{5} \mathrm{OH}$ (ethanol). After $10 \mathrm{mins}, 5 \mathrm{~mL}$ of samples were obtained and diluted with $25 \mathrm{~mL}$ of $70 \%$ ethanol (Antoine et al. 2004; Katwa et al. 1981).
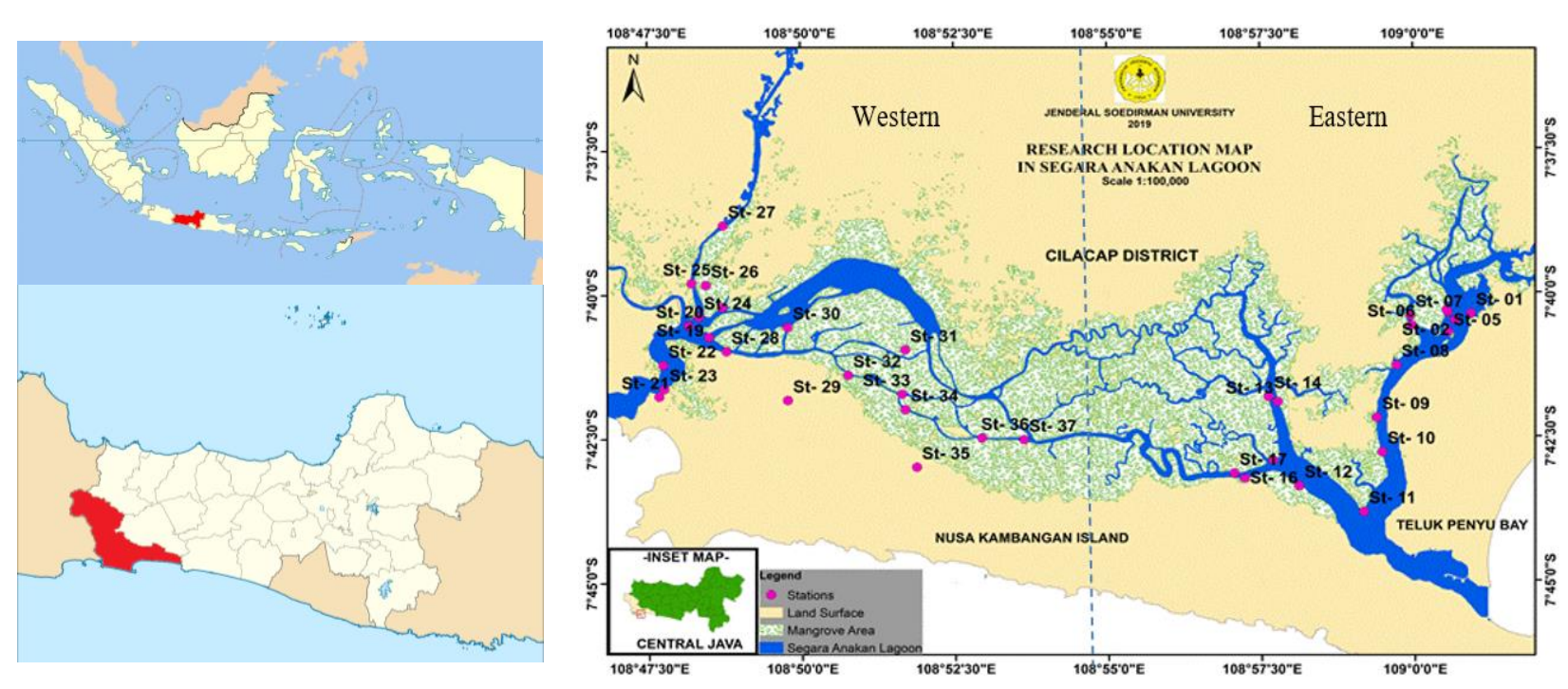

Figure 1. Map of the study area in Segara Anakan Lagoon, Cilacap District, Central Java, Indonesia 
Table 1. List of research stations to collect mangrove samples in Segara Anakan Lagoon, Cilacap District, Central Java, Indonesia

\begin{tabular}{|c|c|c|}
\hline \multirow{2}{*}{ Stations } & \multicolumn{2}{|c|}{ Coordinate } \\
\hline & Latitude (S) & Longitude (E) \\
\hline \multicolumn{3}{|l|}{ West Segara Anakan } \\
\hline Sungai Ujung Gagak & $07 \circ 40^{\prime} 13^{\prime \prime}$ & $108^{\circ} 48^{\prime} 43^{\prime \prime}$ \\
\hline Sungai Lorogan & $07 \circ 40^{\prime} 44^{\prime \prime}$ & $108 \circ 48^{\prime} 30^{\prime \prime}$ \\
\hline Sungai Majingklak & $07 \circ 40^{\prime} 32^{\prime \prime}$ & $108 \circ 48^{\prime} 1 "$ \\
\hline Sungai Mauara Cawitali & $07 \circ 41^{\prime} 46^{\prime \prime}$ & $108 \circ 47^{\prime} 41^{\prime \prime}$ \\
\hline Sungai Kebuyutan & $07 \circ 41^{\prime} 13^{\prime \prime}$ & $108 \circ 47^{\prime} 45^{\prime \prime}$ \\
\hline Sungai Batu Macan & $07 \circ 41^{\prime} 38^{\prime \prime}$ & $108 \circ 47^{\prime} 46^{\prime \prime}$ \\
\hline Sungai Jongor & $07 \circ 40 ' 23 "$ & $108 \circ 48^{\prime} 20^{\prime \prime}$ \\
\hline Sungai Muara Legok & $07 \circ 39 ' 48^{\prime \prime}$ & $108 \circ 48^{\prime} 13^{\prime \prime}$ \\
\hline Sungai Kayu Mati & $07 \circ 39 ' 5 "$ & $108^{\circ} 48^{\prime} 27^{\prime \prime}$ \\
\hline Sungai Langkap & $07 \circ 38^{\prime} 48^{\prime \prime}$ & $108 \circ 48^{\prime} 44^{\prime \prime}$ \\
\hline Sungai Karang Braja & $07 \circ 40^{\prime} 59^{\prime \prime}$ & $108^{\circ} 48^{\prime} 47^{\prime \prime}$ \\
\hline Sungai Klaces & $07 \circ 41^{\prime} 5^{\prime \prime}$ & $108 \circ 49^{\prime} 47^{\prime \prime}$ \\
\hline Sungai Inti Ujung Gagak & 07॰40'34" & $108^{\circ} 49^{\prime} 47^{\prime \prime}$ \\
\hline Sungai Muara Bagian & $07 \circ 40^{\prime} 58^{\prime \prime}$ & $108 \circ 51^{\prime} 42^{\prime \prime}$ \\
\hline Sungai Muara Masigitsela & $07 \circ 41 ' 24 "$ & $108 \circ 50^{\prime} 46^{\prime \prime}$ \\
\hline Sungai Pertigaan Ujung Alang & $07 \circ 41^{\prime} 44$ & $108 \circ 51 ' 39^{\prime \prime}$ \\
\hline Sungai Ujung Alang & $07 \circ 42^{\prime} 0^{\prime \prime}$ & $108 \circ 51^{\prime} 42^{\prime \prime}$ \\
\hline Sungai Dermaga Ujung Alang & $07 \circ 42^{\prime} 6^{\prime \prime}$ & $108 \circ 51$ '53" \\
\hline Sungai Kali Semak & $07 \circ 42^{\prime} 30^{\prime \prime}$ & $108 \circ 52^{\prime} 57^{\prime \prime}$ \\
\hline Sungai Pertigaan Sudiro & $07 \circ 42^{\prime} 32^{\prime \prime}$ & $108 \circ 53^{\prime} 38^{\prime \prime}$ \\
\hline \multicolumn{3}{|l|}{ East Segara Anakan } \\
\hline Kali Panas 1 & $07^{0} 40^{\prime} 22,17^{\prime \prime}$ & $109^{0} 0{ }^{\prime} 56,36^{\prime \prime}$ \\
\hline Kali Panas 2 & $07^{0} 40^{\prime} 28,91^{\prime \prime}$ & $109^{\circ} 0^{\prime} 40,57^{\prime \prime}$ \\
\hline Kali Panas 3 & $07^{0} 40^{\prime} 20,60^{\prime \prime}$ & $109^{0} 0$ '33,62” \\
\hline Kali Panas 4 & $07^{0} 40^{\prime} 18,26 "$ & $109^{0} 0,32,52^{\prime \prime}$ \\
\hline Kali Panas 5 & $07^{0} 40^{\prime} 41,12^{\prime \prime}$ & $109^{0} 0,33,98^{\prime \prime}$ \\
\hline Donan 1 & $07^{0} 40^{\prime} 33,98^{\prime \prime}$ & $108^{0} 59$ ' $58,10^{\prime \prime}$ \\
\hline Donan 2 & $07^{0} 40^{\prime} 23,79^{\prime \prime}$ & $108^{0} 59^{\prime} 56,90 "$ \\
\hline Donan 3 & $07^{0} 41$ ' $15,49 "$ & $108^{0} 59$ ' 43,22 " \\
\hline Donan 4 & $07^{0} 42^{\prime} 10,17^{\prime \prime}$ & $108^{0} 59$ ' $23,75^{\prime \prime}$ \\
\hline Donan 5 & $07^{0} 42,46,06 "$ & $108^{0} 59^{\prime} 29,10$ " \\
\hline Donan 6 (Sleko) & $07^{0} 43^{\prime} 48,07^{\prime \prime}$ & $108^{0} 59$ ' $10,78^{\prime \prime}$ \\
\hline Pelawangan Timur & $07^{0} 43^{\prime} 20,95^{\prime \prime}$ & $108^{0} 58^{\prime} 07,45^{\prime \prime}$ \\
\hline Sapuregel 1 & $07^{0} 41^{\prime} 53,33 ”$ & $108^{0} 57^{\prime} 46,71$ ' \\
\hline Sapuregel 2 & $07^{0} 41^{\prime} 47,97^{\prime}$ & $108^{0} 57^{\prime} 37,81$ ' \\
\hline Sapuregel 3 & $07^{0} 42^{\prime} 54,20 "$ & $108^{0} 57^{\prime} 42,07$ ' \\
\hline Kembang Kuning1 & $07^{0} 43^{\prime} 12,88^{\prime \prime}$ & $108^{0} 57^{\prime} 14,24$ "' \\
\hline Kembang Kuning2 & $07^{0} 43^{\prime} 07,52^{\prime \prime}$ & $108^{0} 57^{\prime} 03,97$ ' \\
\hline
\end{tabular}

\section{Analysis of tannin content procedure}

The percent and weight of mangrove tannin were measured and calculated using UV-Visible Spectrophotometry with low-grade elements to determine the compound level percentage as a chromosphere structure. The percentage of mangrove tannin was measured by the absorbance method with the largest wavelength analysis of UV spectrophotometer. The UVvisible spectrophotometer was also used to calculate absorbed and reflected lights by calibrating the relative curve formula among the concentration series for the lowgrade element analysis. Also, the UV method used the optical density principles of benzene chromosphere groups, which were related to the phenolic and tannin solutions at 280 nm (Antoine et al. 2004; Katwa et al. 1981).

\section{Data analysis}

Clustering tannin content

Clustering tannin content across mangrove species used euclidian distance analysis (Ludwig and Renold 1988) using following methods:

Stage 1. Calculation of Euclidian distance (ED) between species-i and species-j

$$
E D_{j k}=\sqrt{\sum_{i=1}^{s}(x i j-x i k)^{2}}
$$

Stage 2. Calculation distance between Euclidian among mangrove species

$$
D(j, k) h=\propto_{1} D(j, h)+\propto_{2} D(k, h)+\beta D(j, k)
$$

\begin{tabular}{llllll}
\hline Stations & $\mathbf{2}$ & $\mathbf{3}$ & $\mathbf{4}$ & $\mathbf{. .}$ & $\mathbf{n}$ \\
\hline 1 & $\mathrm{ED} 12$ & $\mathrm{ED} 13$ & $\mathrm{ED}_{14}$ & & \\
2 & & $\mathrm{ED} 23$ & $\mathrm{ED}_{24}$ & & \\
3 & & & $\mathrm{ED}_{34}$ & & \\
& & & $\ldots$ & & \\
$\mathrm{N}$ & & & $\mathrm{ED}_{\text {n4 }}$ & & \\
\hline
\end{tabular}

Note: Edjk is Euclidean Distance, $\mathrm{i}$ is species, $\mathrm{X} i \mathrm{j}$ is density in station- $j, \mathrm{X} i k$ is density in station- $k, \mathrm{D}$ is Distance, $\alpha 1$ is 0.625 , $\alpha 2$ is 0.625 and $\beta$ is -0.25

\section{Distribution of tannin across plant parts}

The mangrove tannin distribution was analyzed used table stock analysis (initial stock, minimum stock, maximum stock and average stock). This analysis was used to describe distribution of mangrove tannins across plant parts for each mangrove species.

\section{Distribution of tannin across landscape}

The distribution of tanning across landscape was constructed by the distribution of its percent and weight from mangrove species. The landscaping of tannin showed the distribution of mangrove species in this ecosystem, following the characteristic environment, site, and potentials, as the main variable of this landscape. This landscaping aimed to develop the species zonation using tannin as an ecosystem service of mangrove ecosystem.

\section{RESULTS AND DISCUSSION}

\section{Tannins contained in mangrove samples}

Mangrove tannins were contained in the leaves, barks, and stems (samples total are 342 samples from 19 mangrove species with three tree replicates/species). The content of the tannins is shown in Table 2. The tannin in mangrove stems and barks was $253.6 \mathrm{mg}$ g- 1 or contributed to $67 \%$ total tannins in the samples while the tannin in mangrove leaves was $127.2 \mathrm{mg}$ g-1 or $33 \%$ of the samples (Table 2).

As shown in Table 2, the barks and stems consisted a higher tannins than those in the leaves. Matsutani and Nagai (2013) found that tannin contents in the leaves of nine mangrove species ranged from 14.56 to $40.11 \%$ (dry 
wt). This result suggests that bark and stem of mangrove vegetation are main sources of tannin, which is similar to the results of research by Abdullah and Lee (2017), Rahim et al. (2008a), and Rahim et al. (2008). Basically, mangrove tannins were made up of chemical compounds of tannin-B and A-ring phenolic carbons (Hernes et al. 2001). Rahim et al. (2008) also discussed that the potential extractive matter of Rhizophora spp. stem had depolymerization activity of nucleophile phloroglucinol in order to develop the ethanol extractive agent. Furthermore, Tan and Kassim (2011) also analyzed stems and barks of $R$. apiculata to produce potential tannins, isopropyl proteins, and alcohol.

The higher tannin content in barks and stems than in the leaves of mangroves because bark and stem have cellulose, hemicellulose, lignin and extractive matters ( $\mathrm{Li}$ et al. 2015; Patay et al. 2016; Sharma 2019; Martins et al. 2020). The potential tannin from barks and stems ranged 198.7 to $291.8 \mathrm{mg} / \mathrm{g}$, while the leaves had tannin between 97.8 and $145.6 \mathrm{mg} / \mathrm{g}$.

\section{Composition of tannin in mangrove species}

The composition of tannin in each mangrove species is shown in Table 3. The composition of tannin percentage shows the potential of extractive matters (including tannin) of mangrove species which correlates with the photosynthesis metabolism.

Table 2. Tannin contents in the samples of stems, barks and leaves of mangrove in Segara Anakan Lagoon, Cilacap, Indonesia

\begin{tabular}{lcc}
\hline Part of mangrove & $\begin{array}{c}\text { Tannin weight } \\
(\mathbf{m g} / \mathbf{g})\end{array}$ & $\begin{array}{c}\text { Percentage of } \\
\text { tannins (\%) }\end{array}$ \\
\hline Leaves (171 samples) & 127.2 & 33.40 \\
Barks and stems (171 samples) & 253.6 & 66.60 \\
Average & 215.7 & \\
\hline
\end{tabular}

Table 3. The composition of tannin in mangrove species in Segara Anakan Lagoon, Cilacap, Indonesia

\begin{tabular}{lcccc}
\hline \multirow{3}{*}{ Mangrove species } & \multicolumn{3}{c}{ Tannin percentage (\%) } \\
\cline { 2 - 5 } & \multicolumn{3}{c}{ Barks and stems } & \multicolumn{2}{c}{ Leaves } \\
\cline { 2 - 5 } & Average & Sd & Average & Sd \\
\hline Acacia auriculifromis & 26.73 & 2.24 & 12.89 & 1.12 \\
Acanthus ilicifolius & 21.36 & 1.65 & 11.26 & 1.01 \\
Aegiceras floridum & 26.15 & 2.35 & 11.93 & 1.11 \\
Avicennia alba & 24.66 & 2.14 & 13.30 & 1.21 \\
Bruguiera gymnorrhiza & 19.87 & 1.15 & 13.45 & 1.2 \\
Ceriops decandra & 25.80 & 2.34 & 11.37 & 1.04 \\
Ceriops tagal & 25.73 & 2.23 & 11.27 & 1.01 \\
Exoecaria agallocha & 27.18 & 3.21 & 12.08 & 1.22 \\
Heritiera littoralis & 29.18 & 3.22 & 12.88 & 1.21 \\
Hibiscus tiliaceus & 26.17 & 2.05 & 9.78 & 0.98 \\
Melaleuca leucadendron & 23.37 & 2.11 & 11.26 & 1.12 \\
Nypa fruticans & 28.12 & 3.01 & 14.56 & 1.47 \\
Rhizophora apiculata & 25.30 & 2.05 & 13.76 & 1.38 \\
Rhizophora mucronata & 25.65 & 2.10 & 14.50 & 1.5 \\
Rhizophora stylosa & 23.40 & 1.54 & 12.67 & 1.28 \\
Sonneratia alba & 26.80 & 2.21 & 13.15 & 1.3 \\
Sonneratia caseolaris & 26.17 & 2.22 & 13.05 & 1.3 \\
Xylocarpus granatum & 24.36 & 2.01 & 12.08 & 1.21 \\
Xylocarpus moluccensis & 26.64 & 2.34 & 12.10 & 1.22 \\
\hline
\end{tabular}

The data in Table 3 shows that Xylocarpus moluccensis, Exoecaria agallocha, Nypa fruticans, and Heritiera littoralis are the mangrove species with the highest tannin contents. The percentage of mangrove tannin ranged between $9.78-14.56 \%$ in leaves, and $19.87-29.18 \%$ in stem and barks. This result implies species' capability to produce tannin as extractive matter of mangrove vegetation (Rahim et al. 2008a; Hilmi et al. 2017).

Mangrove tannins are complex mixtures of biodegradable polyphenolic, non-toxic, and extracted compounds. The mangrove compound has two different classes of polyphenolic components including the condensed and hydrolyzed tannins (Nardeli et al. 2019). Also, the percentage of mangrove tannins has correlation with carbon content and organic compound, which are arranged by cellulose (Hilmi et al. 2017), hemicellulose, and extractive matter (Duncanson et al. 2017; Hilmi et al. 2019a).

Table 3 also show that the percentage of mangrove tannin is within the range of 7.2-14.3\% (leaves) and 14.2$29.3 \%$ (stem and bark). The table also shows that many species had mangrove tannin percentage $>20 \%$ such as $H$. littoralis, N. fruticans, Excoecaria agallocha, Aegiceras floridum, Ceriops decandra, Ceriops tagal, $R$. mucronata, $R$. apiculata, Sonneratia alba, S. caseolaris, and Xylocarpus moluccensis. Matsutani and Nagai (2013) and Hilmi et al. (2015) state that the potential of phenolic compounds, such as mangrove tannin, was produced by plant's leaves, roots, woods, barks, fruits, and buds. Further, the abundance of mangrove tannins is composed by $20 \%$ of dry weight.

\section{Classification of mangrove tannin percentage}

The classification of mangrove tannin percentage used the frequency class analysis (Willard 2020) and is shown in Table 4 . The table shows that mangroves in our study area had five classes of tannin percentage which were arranged by potentials of stems and barks (19-32\%) and leaves (8$17 \%)$. H. littoralis had the highest percentage of bark and stem tannin, between $29-33 \%$, while $R$. mucronata and $N$. fruticans had high percentage of leaves tannin with 14$17 \%$. The percentage of mangrove tannin has correlation with productivity of phytopathogen, antibiotics, tanners, and wood adhesives (Hernes et al. 2001; Rahim et al. 2008; Martins et al. 2020).

The classification of mangrove tannin percentage indicates the differential composition of both hydrolyzable tannins and hydrolysis of gallotannins. The percentage of the mangrove compound further explained the presence of C-C chains of tannin compounds (Negri and Tabach 2013), composition of lignin, with the potential of antioxidant and antimicrobial agents, in order to protect the plant's selfdefense (Medini et al. 2014; Rahim et al. 2008; Rahim et al. 2008). Tannins provide many benefits for plants, such as protection against insects, pathogens, and herbivore animals (Cohen et al. 2009; Subandriyo and Setianingsih 2016; Mostafa et al. 2018; Sharma 2019). 
Table 4. The classification of mangrove species in Segara Anakan Lagoon, Cilacap, Indonesia based on the percentage of tannin contained in plant parts.

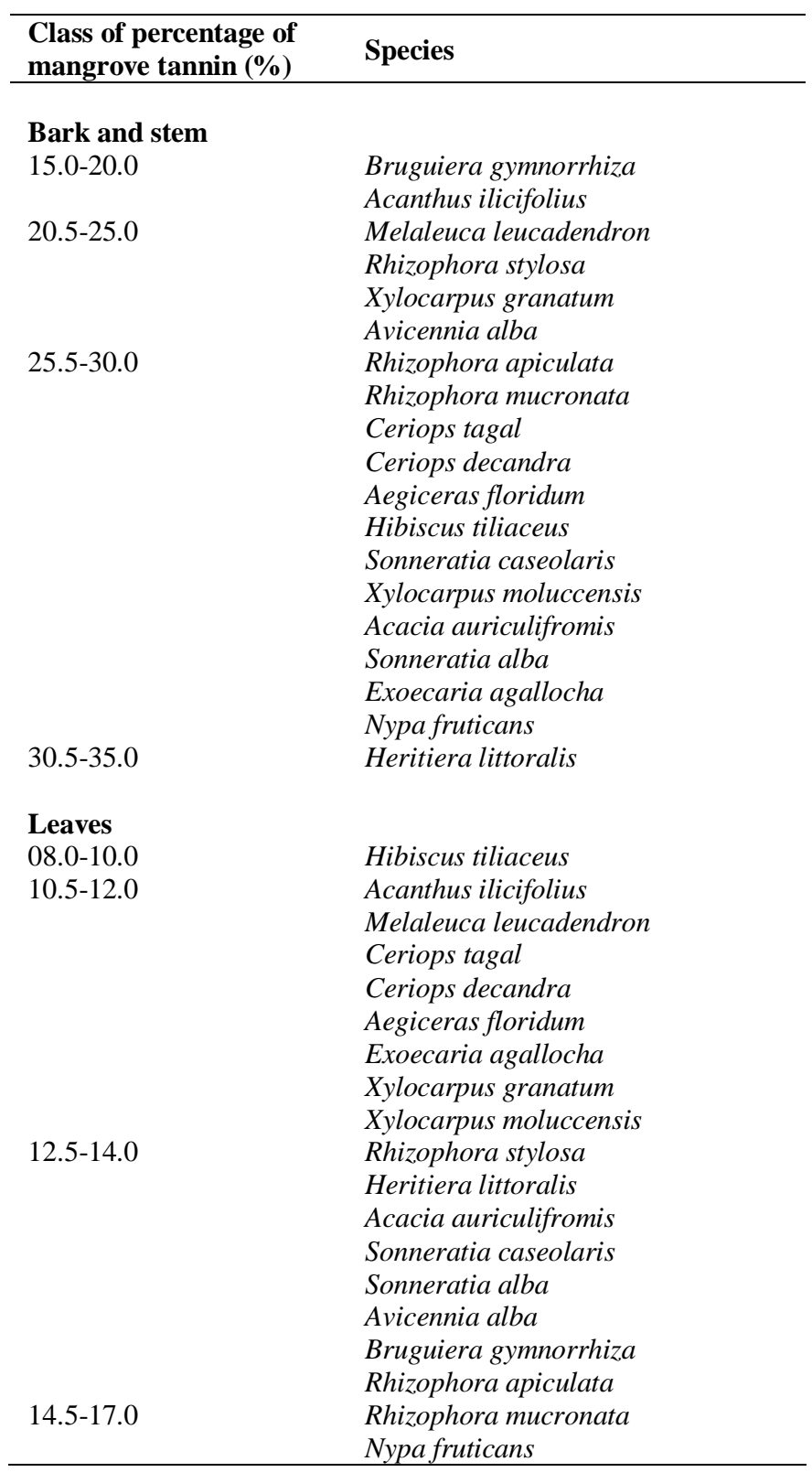

Rahim et al. (2008a) also mentioned that Rhizophora spp (R. mucronata, R. mangle, and $R$. apiculata) had the highest tannin composition due to the fact that they contain antioxidants, precipitate pectinase, amylase, lipase, protease, $\beta$-galactosidase, cellulose, and other macromolecules (Sharma 2019). They also contain the highest complex macromolecular polyphenolic and natural polymers, such as cellulose, hemicellulose, and lignin (Pan et al. 2019; Ray et al. 2012; Verheyden et al. 2005)

\section{Total tannin content in mangrove plant}

The total tannin content in mangrove plants ranged between 0.59-158.96 kg/trees (bark and stem) and 0.20$91.65 \mathrm{~kg} /$ trees (leaves) (Tables 5 and 6). R. apiculata and $R$. mucronata had the highest total tannin $(158.96 \mathrm{~kg} /$ trees $)$.
The total tannin has correlation with the biomass of barks, stems, and leaves (Hilmi et al. 2019a; Taillardat et al. 2018), carbon content, organic compound, and extractive matter. The results showed in Tables 5 and 6 suggest that $R$. apiculata, $R$. mucronata, $S$. alba, Xylocarpus moluccensis, Exoecaria agallocha, N. fruticans, and Heritiera littoralis have the potential to supply the raw materials of tannin industry (Bello et al. 2020) Our data also showed that the total tannins in mangrove species bigger than those from black acacia, Acacia mearnsii, and other breeds which ranged between $25.57-97.89 \mathrm{mg} \mathrm{g}^{-1}(\mathrm{Li}$ et al. 2015; Nardeli et al. 2019). Accordingly, Salar et al. (2017), also mentioned that the potential of condensed tannins obtained from cultivars ranged between 40.96$99.91 \mathrm{mgCE} / 100 \mathrm{~g}$, with coffee fruit at $0.402-1.46 \%$ (Patay et al. 2016), and medicinal plants at 17.15-44.02\% (Moura et al. 2016).

Table 6 shows that total tannin content in mangrove plants can be classified into five classes: Class 1, which is the largest total mangrove tannins and consists of $R$. apiculata and R. mucronata; Class 2, which consists of $S$. alba, S. caseolaris, Xylocarpus granatum, Avicennia alba/marina, Acacia auriculifromis, Aegiceras floridum, and Xylocarpus moluccensis; Class 3, which includes Ceriops spp., Bruguiera gymnorrhiza, and Rhizophora stylosa; Class 4, which consists of Melaleuca leucadendron, Exoecaria agallocha, H. littoralis, Hibiscus tiliaceus, and Nypa fruticans; and Class 5, which includes Acanthus ilicifolius. The mangrove tannin content in classes 1 to 3 are still bigger than Anadenanthera falcata, Lafoensia replicata, and Hymenaea stigonocarpa as found by a study (Monteiro et al. 2014).

The regression analysis showed that potential tannin (in $\mathrm{kg}$ ) can be estimated using the following formula

$$
\text { Potential tannin }(\mathrm{kg})=-67.9+5.87 \text { diameter }(\mathrm{cm})
$$

in which the regression has strong correlation with 0.70 and variance analysis as presented in Table 7 . This result suggests that the potential tannin of mangrove species has high significant correlation with trees diameter. This is not surprising since mangrove diameter will influence potential of cellulose, hemicellulose, lignin and extractive matter ( $\mathrm{Li}$ et al. 2015; Martins et al. 2020; Patay et al. 2016; Sharma 2019).

\section{Cluster of mangrove tannins}

Cluster of mangrove tannin shows specific and similar distances based on the percentage and weight of the compound (Ludwig and Renold 1988; Rachmatin 2014; Rachmawati 2019) (Figure 2). The data explained that Ceriops decandra-C. tagal, Acacia auriculiformis-S. alba, $S$. caseolaris- $X$. granatum, and Avicennia marina- $R$. apiculata, are in cluster of species having the highest similarities.

Furthermore, Figure 3 shows boxplot of the clustering of mangrove tannins. Based on the tannins contained, mangrove vegetation in Segara Anakan Lagoon has four clusters: Cluster 1, consists of ((A. auriculiformis, S. alba), S. caseolaris), (Acanthus ilicifolius, Xylocarpus 
moluccensis), Excoecaria agallocha); Cluster 2, consists of (((C. decandra, C. tagal),(A. marina, R. apiculata), $R$. mucronata); and Cluster 3, consists of ((Hibiscus tiliaceus,
(H. littoralis, N. fruticans)) and Cluster 4, dominated by ((Acanthus ilicifolius, (Melaleuca Leucadendron, (Rhizophora stylosa, X. granatum), Bruguiera gymnorrhiza).

Table 5. Total tannin content in mangrove species in Segara Anakan Lagoon, Cilacap, Indonesia

\begin{tabular}{|c|c|c|c|c|c|c|c|c|c|c|c|c|}
\hline \multirow{4}{*}{ Mangrove species } & \multicolumn{12}{|c|}{ Range of tannin total (kg/trees) } \\
\hline & \multicolumn{4}{|c|}{10} & \multicolumn{4}{|c|}{20} & \multicolumn{4}{|c|}{30} \\
\hline & \multicolumn{2}{|c|}{ Barks and stems } & \multicolumn{2}{|c|}{ Leaves } & \multicolumn{2}{|c|}{ Barks and stems } & \multicolumn{2}{|c|}{ Leaves } & \multicolumn{2}{|c|}{ Barks and stems } & \multicolumn{2}{|c|}{ Leaves } \\
\hline & Max & Min & Max & Min & Max & Min & Max & Min & Max & Min & Max & Min \\
\hline Acacia auriculifromis & 5.77 & 4.88 & 1.86 & 1.56 & 31.99 & 27.04 & 10.31 & 8.66 & 87.09 & 73.62 & 42.12 & 35.38 \\
\hline Acanthus ilicifolius & 0.68 & 0.59 & 0.24 & 0.20 & 3.79 & 3.25 & 1.35 & 1.13 & 10.32 & 8.84 & 5.51 & 4.60 \\
\hline Aegiceras floridum & 7.07 & 5.90 & 2.16 & 1.79 & 35.80 & 29.90 & 10.92 & 9.06 & 92.45 & 77.21 & 42.30 & 35.10 \\
\hline Avicennia alba & 6.68 & 5.62 & 2.41 & 2.01 & 34.12 & 28.67 & 12.32 & 10.26 & 88.55 & 74.41 & 47.94 & 39.95 \\
\hline Bruguiera gymnorrhiza & 4.79 & 4.27 & 2.23 & 1.86 & 23.75 & 21.15 & 11.04 & 9.23 & 60.60 & 53.97 & 42.23 & 35.31 \\
\hline Ceriops decandra & 6.98 & 5.82 & 2.05 & 1.71 & 35.35 & 29.47 & 10.39 & 8.65 & 91.29 & 76.10 & 40.26 & 33.51 \\
\hline Ceriops tagal & 6.94 & 5.83 & 2.03 & 1.70 & 35.12 & 29.52 & 10.28 & 8.59 & 90.70 & 76.23 & 39.84 & 33.28 \\
\hline Exoecaria agallocha & 1.86 & 1.47 & 0.54 & 0.44 & 7.44 & 5.87 & 2.17 & 1.77 & 16.74 & 13.20 & 7.33 & 5.98 \\
\hline Heritiera littoralis & 1.98 & 1.59 & 0.57 & 0.48 & 7.93 & 6.36 & 2.30 & 1.90 & 17.85 & 14.30 & 7.76 & 6.43 \\
\hline Hibiscus tiliaceus & 1.73 & 1.48 & 0.44 & 0.36 & 6.91 & 5.90 & 1.76 & 1.44 & 15.54 & 13.29 & 5.93 & 4.85 \\
\hline Melaleuca leucadendron & 1.56 & 1.30 & 0.51 & 0.41 & 6.24 & 5.20 & 2.02 & 1.65 & 14.03 & 11.71 & 6.82 & 5.59 \\
\hline Nypa fruticans & 1.91 & 1.54 & 0.65 & 0.53 & 7.62 & 6.15 & 2.62 & 2.14 & 17.15 & 13.83 & 8.83 & 7.21 \\
\hline Rhizophora apiculata & 10.14 & 8.62 & 3.74 & 3.06 & 54.28 & 46.15 & 20.03 & 16.38 & 144.81 & 123.10 & 80.16 & 65.55 \\
\hline Rhizophora mucronata & 8.37 & 7.10 & 3.22 & 2.61 & 53.62 & 45.51 & 20.61 & 16.75 & 158.96 & 134.90 & 91.65 & 74.47 \\
\hline Rhizophora stylosa & 3.82 & 3.35 & 1.43 & 1.16 & 18.82 & 16.50 & 7.02 & 5.73 & 47.82 & 41.92 & 26.75 & 21.84 \\
\hline Sonneratia alba & 7.23 & 6.13 & 2.40 & 1.97 & 36.93 & 31.31 & 12.26 & 10.06 & 95.85 & 81.25 & 47.74 & 39.15 \\
\hline Sonneratia caseolaris & 7.08 & 5.97 & 2.39 & 1.95 & 36.14 & 30.49 & 12.18 & 9.97 & 93.80 & 79.13 & 47.41 & 38.82 \\
\hline Xylocarpus granatum & 5.07 & 4.29 & 1.70 & 1.39 & 30.50 & 25.85 & 10.25 & 8.38 & 87.18 & 73.89 & 43.94 & 35.94 \\
\hline Xylocarpus moluccensis & 5.57 & 4.67 & 1.71 & 1.39 & 33.52 & 28.10 & 10.27 & 8.39 & 95.79 & 80.32 & 44.04 & 35.97 \\
\hline
\end{tabular}

Table 6. Classification of mangrove species in Segara Anakan Lagoon, Cilacap, Indonesia based on total tannin content

\begin{tabular}{lll}
\hline Class & Species & $\begin{array}{l}\text { Max. of tannin } \\
\text { total (kg/trees) }\end{array}$ \\
\hline 1 & $\begin{array}{l}\text { Rhizophora apiculata } \\
\text { Rhizophora mucronata }\end{array}$ & $386.60-460.38$ \\
2 & $\begin{array}{l}\text { Xylocarpus moluccensis } \\
\text { Acacia auriculifromis } \\
\text { Aegiceras floridum }\end{array}$ & $230.22-258.55$ \\
& Avicennia alba \\
& Sonneratia alba & \\
& Sonneratia caseolaris & \\
& Xylocarpus granatum & \\
& Bruguiera gymnorrhiza & $167.57-227.58$ \\
& Ceriops decandra & \\
& Ceriops tagal & \\
& Rhizophora stylosa & $32.21-39.64$ \\
& Exoecaria agallocha & \\
& Heritiera littoralis & \\
& Hibiscus tiliaceus & \\
& Melaleuca leucadendron & \\
& Nypa fruticans & \\
& Acanthus ilicifolius & $25.23-27.90$ \\
\hline
\end{tabular}

Table 7. Analysis of variance potential of regression analysis on the correlation between mangrove tannin $(\mathrm{kg})$ and diameter $(\mathrm{sm})$

\begin{tabular}{lccccc}
\hline Source & DF & SS & MS & F & P \\
\hline Regression & 1 & 327523 & 327523 & 65.23 & 0.000 \\
Residual Error & 74 & 371559 & 5021 & & \\
Total & 75 & 699082 & & & \\
\hline
\end{tabular}

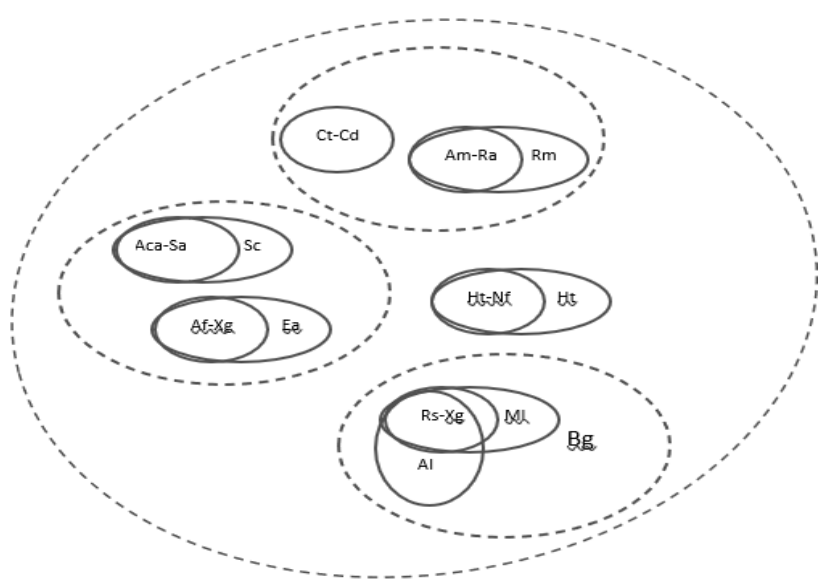

Figure 3. The boxplot of clustering analysis of mangrove species in Segara Anakan Lagoon, Cilacap, Indonesia based on tannin content

Basically, the clustering of mangrove tannins is influenced by nutrient absorption and environmental factors since one cluster has different characteristics from other groups (Rachmawati 2019; Widowati 2018). Using the density, Rachmawati (2019) and Widowati (2018) discussed that the mangrove ecosystem in Western and Eastern Segara Anakan had three clusters, respectively. Also, the clusterings of mangrove tannin and density are different because the compound among species is related to vegetation ability to produce extractive matter (i.e. tannin). 


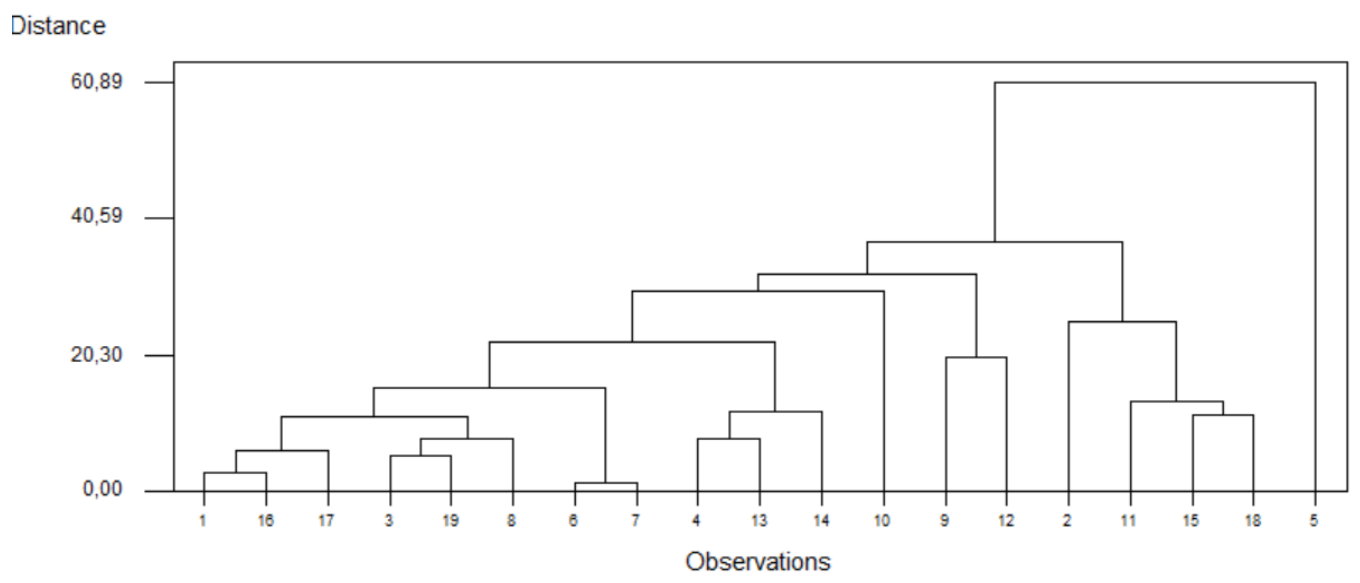

Figure 2. The dendrogram of clustering analysis of mangrove species in Segara Anakan Lagoon, Cilacap, Indonesia based on tannin content. Note: 1. Aciacia auriculiformis, 2. Acanthus ilicifolius, 3. Aegiceras floridum, 4. Avicennia marina, 5. Bruguiera gymnorrhiza, 6. Ceriops decandra, 7. Ceriops tagal, 8. Excoecaria agallocha, 9. Heritiera littolaris, 10. Hibiscus tiliaceus, 11. Melaleuca leucadendron, 12. Nypa fruticans, 13. Rhizophora apiculata, 14. Rhizophora mucronata, 15. Rhizophora stylosa, 16. Sonneratia alba, 17. Sonneratia caseolaris, 18. Xylocarpus granatum, 19. Xylocarpus moluccensis

In conclusion, tannins in mangrove vegetation in Segara Anakan Lagoon, Cilacap, Indonesia were contained in barks and stems (66.6\%) and leaves (33.4\%). The percentage of tannin composition ranged $21.36-29.18 \%$ in barks and stems and 9.78-14.50\% in leaves. Mangrove species had varying tannin percentage with $H$. littoralis, $N$. fruticans, Excoecaria agallocha, Xylocarpus moluccensis, and $S$. alba having the highest tannin percentage. The total tannin content in mangrove plant were the largest in $R$. apiculata and $R$. mucronata. The clustering of mangrove tannin also showed that $C$. decandra-C. tagal, $A$. auriculiformis-S. alba, S. caseolaris-X. granatum, and A. marina-R. apiculata had high tannin percentage similarities with weight of the compound distributed at 0.59-10.14 $\mathrm{kg} /$ trees (bark and stem with diameter $>10 \mathrm{~cm}$ ) and 0.20 $3.74 \mathrm{~kg} /$ trees (leaves with diameter $>10 \mathrm{~cm}$ ), till 8.84 $158.96 \mathrm{~kg} /$ trees (bark and stem with diameter $>40 \mathrm{~cm}$ ) and $4.60-91.65 \mathrm{~kg} /$ trees (leaves with diameter $>40 \mathrm{~cm}$ ).

\section{ACKNOWLEDGEMENTS}

The authors thank Universitas Jenderal Soedirman (Unsoed), Banyumas, Indonesia for the support on this research with Unsoed Grant (Riset Institusi 2021), and the Dean of Faculty of Fisheries and Marine Sciences, Unsoed. The gratitude also goes to the researcher colleagues for their valuable advice.

\section{REFERENCES}

Abdullah MM, Lee SY. 2017. Structure of mangrove meiofaunal assemblages associated with local sediment conditions in subtropical Eastern Australia. Estuar Coast Shelf Sci 198: 438-449. DOI: 10.1016/j.ecss.2016.10.039.
Antoine M, Simon C, Pizzi A. 2004. UV spectrophotometric method for polyphenolic tannin analysis. J Appl Polymer Sci 91 (2): 2729-2732. DOI: 10.1002/app.13481.

Avelar S, van der Voort TS, Eglinton TI. 2017. Relevance of carbon stocks of marine sediments for national greenhouse gas inventories of maritime nations. Carbon Balance Manag 12 (1): 1-10. DOI: 10.1186/s13021-017-0077-x.

Bahru T, Ding Y. 2020. Effect of stand density, canopy leaf area index and growth variables on Dendrocalamus brandisii (Munro) Kurz litter production at Simao District of Yunnan Province, southwestern China. Glob Ecol Conserv 23: e01051. DOI: 10.1016/j.gecco.2020.e01051.

Bello A, Virtanen V, Salminen J, Leiviskä T. 2020. Aminomethylation of spruce tannins and their application as coagulants for water clarification. Separat Purif Technol 242: 116765. DOI: 10.1016/j.seppur.2020.116765.

Bellotti N, del Amo B, Romagnoli R. 2012. Caesalpinia spinosa tannin derivatives for antifouling formulations. Proc Mater Sci 1 (221): 259265. DOI: 10.1016/j.mspro.2012.06.035.

Cohen MCL, Guimaraes JTF, Franca M, Lara RJ, Behling H. 2009. Tannin as an indicator of paleomangrove in sediment cores from Amapa. Wetl Ecol Manag 17 (2): 145-155. DOI: 10.1007/s11273008-9100-z.

Domínguez-domínguez M, Zavala-cruz J, Rincón-ramírez JA, Martínezzurimendi P. 2019. Management strategies for the conservation, restoration and utilization of mangroves in Southeastern Mexico. Wetlands 39 (5): 907-919. DOI: 10.1007/s13157-019-01136-z.

Duncanson L, Huang W, Johnson K, Swatantran A, McRoberts RE, Dubayah R. 2017. Implications of allometric model selection for county-level biomass mapping. Carbon Balance Manag 12 (1): 1-11. DOI: 10.1186/s13021-017-0086-9.

El-Ashmawy IM, Al-Wabel NA, Bayad AE. 2016. Achillea fragrantissima, rich in flavonoids and tannins, potentiates the activity of diminazene aceturate against Trypanosoma evansii in rats. Asian Pac J Trop Med 9 (3): 228-234. DOI: 10.1016/j.apjtm.2016.01.032.

Erickson AA, Bell SS, Dawes CJ. 2012. Associational resistance protects mangrove leaves from crab herbivory. Acta Oecologica 41, 46-57. DOI: 10.1016/j.actao.2012.04.002.

Hernes PJ, Benner R, Cowie GL, Goi MA, Bergamaschi BA, Hedges JI. 2001. Tannin diagenesis in mangrove leaves from a tropical estuary: A novel molecular approach. Geochim Cosmochim Acta 65 (18): 3109-3122. DOI: 10.1016/S0016-7037(01)00641-X.

Hidayati NV, Hilmi E, Haris A, Effendi H, Guiliano M, Doumenq P, Syakti AD. 2011. Fluorene removal by biosurfactants producing Bacillus megaterium. Waste Biomass Valorization 2 (4): 415-422. DOI: 10.1007/s12649-011-9085-3. 
Hilmi E. 2018. Mangrove landscaping using the modulus of elasticity and rupture properties to reduce coastal disaster risk. Ocean Coast Manag 165: 71-79. DOI: 10.1016/j.ocecoaman.2018.08.002.

Hilmi E, Kusmana C, Suhendang E, Iskandar. 2017. Correlation analysis between seawater intrusion and mangrove Greenbelt. Indones $\mathbf{J}$ For Res 4 (2): 151-168. DOI: 10.20886/ijfr.2017.4.2.151-168.

Hilmi E, Pareng R, Vikaliana R, Kusmana C, Iskandar Sari LK, Setijanto. 2017. The carbon conservation of mangrove ecosystem applied for REDD program. Regional Stud Mar Sci 16: 152-161. DOI: 10.1016/j.rsma.2017.08.005.

Hilmi E, Sari LK, Cahyo TN, Kusmana C, Suhendang E. 2019. Carbon sequestration of mangrove ecosystem in Segara Anakan Lagoon, Indonesia. Biotropia 26 (3): 181-190. DOI: 10.11598/BTB.2019.26.3.1099.

Hilmi E, Sari LK, Cahyo TN, Mahdiana A, Samudra SR. 2021. The affinity of mangrove species using Association and Cluster Index in North Coast of Jakarta and Segara Anakan of Cilacap, Indonesia. Biodiversitas 22 (7): 2907-2918. DOI: 10.13057/biodiv/d220743.

Hilmi E, Sari LK, Setijanto. 2019. The mangrove landscaping based on water quality: (Case study in Segara Anakan Lagoon and Meranti Island). IOP Conf Ser: Earth Environ Sci 255 (1): 012028. DOI: 10.1088/1755-1315/255/1/012028.

Hilmi E, Siregar AS, Febryanni L. 2015. Struktur komunitas, zonasi dan keanekaragaman hayati vegetasi mangrove di Segara Anakan Cilacap. Omni-Akuatika 11 (2): 20-32. DOI: 10.20884/1.oa.2015.11.2.36.

Hilmi E, Siregar AS, Syakti AD. 2017. Lead (Pb) distribution on soil, water and mangrove vegetation matrices in Eastern Part of Segara Anakan Lagoon, Cilacap. Omni-Akuatika 13 (2): 25-38. DOI: 10.20884/1.oa.2017.13.2.83

Hilmi E, Sari LK, Cahyo TN, Kusmana C, Suhendang. E. 2019. Carbon sequestration of mangrove ecosystem in Segara Anakan Lagoon, Indonesia. Biotropia $26 \quad$ (3): 181-190. DOI : 10.11598/bcb.2019.26.3.1099.

Jia R, Liu D, Lu J, Zhang G. 2020. Wetland destruction on migration routes threatens a breeding population of the endangered black-faced spoonbill (Platalea minor). Global Ecol Conserv 23, e01105. DOI: 10.1016/j.gecco.2020.e01105.

Jinhui S, Sudong X, Yan N, Xia P, Jiahao Q, Yongjian X. 2019. Effects of microplastics and attached heavy metals on growth, immunity, and heavy metal accumulation in the yellow seahorse, Hippocampus kuda. Mari Pollut Bull 149 (June): 110510. DOI: 10.1016/j.marpolbul.2019.110510.

Katwa LC, Ramakrishna M, Rao MRR. 1981. Spectrophotometric assay of immobilized tannase. J Biosci 3 (2): 135-142. DOI 10.1007/BF02702656.

Lei P, Zhong H, Duan D, Pan K. 2019. A review on mercury biogeochemistry in mangrove sediments: Hotspots of methylmercury production? Sci Tot Environ 680, 140-150. DOI: 10.1016/J.SCITOTENV.2019.04.451.

Li Y, Ding P, Huang C, Lu S. 2015. Total tannin content of foods of François' Langur in Fusui, Guangxi, China: Preliminary study. Acta Ecol Sin 35 (1): 16-22. DOI: 10.1016/j.chnaes.2014.12.005.

Liu J, Wang L, Li J, Li C, Zhang S, Gao Q, Zhang W, Li J. 2020. Degradation mechanism of Acacia mangium tannin in $\mathrm{NaOH} / \mathrm{urea}$ aqueous solution and application of degradation products in phenolic adhesives. Int $\mathrm{J}$ Adhesion Adhesives 98, 102556. DOI: 10.1016/j.ijadhadh.2020.102556.

Ludwig J, Renold J. 1988. Statistical Ecology (A primer on Methods and Computing). John Wiley Sons. Inc., New York.

Mak YW, Chuah L. O, Ahmad R, Bhat R. 2013. Antioxidant and antibacterial activities of hibiscus (Hibiscus rosa-sinensis L) and cassia (Senna bicapsularis L) flower extracts. J King Saud Univ Sci 25 (4): 275-282. DOI: 10.1016/j.jksus.2012.12.003.

Martins RO, Gomes IC, Mendonça Telles AD, Kato L, Souza PS, Chaves AR. 2020. Molecularly imprinted polymer as solid-phase extraction phase for condensed tannin determination from Brazilian natural sources. J Chromatograph A 1620: 460977. DOI: 10.1016/j.chroma.2020.460977.

Matsutani T, Nagai T. 2013. Elution of dissolved Fe from mangrove soil by tannin solution. Wetl Ecol Manag 21 (2): 107-115. DOI 10.1007/s11273-013-9282-x.

Medini F, Fellah H, Ksouri R, Abdelly C. 2014. Total phenolic, flavonoid and tannin contents and antioxidant and antimicrobial activities of organic extracts of shoots of the plant Limonium delicatulum. J $\begin{array}{llll}\text { Taibah University Sci } 8 & (3): & 216-224 & \text { DOI: }\end{array}$ 10.1016/j.jtusci.2014.01.003.
Monteiro JM, de Souza JSN, Lins Neto EMF, Scopel K, Trindade EF. 2014. Does total tannin content explain the use-value of spontaneous medicinal plants from the Brazilian semi-arid region? Braz J Pharmacog 24 (2): 116-123. DOI: 10.1016/j.bjp.2014.02.001.

Mostafa AA, Al-askar AA, Almaary KS, Dawoud TM, Sholkamy EN, Bakri MM. 2018. Antimicrobial activity of some plant extracts against bacterial strains causing food poisoning diseases. Saudi J Biol Sci 25 (2): 361-366. DOI: 10.1016/j.sjbs.2017.02.004

Murry BA. 2019. Wetland conservation requires transition toward landscape-scale interdisciplinary approaches. Wetlands 39 (6): 12491254. DOI: 10.1007/s13157-019-01237-9.

Nardeli JV Fugivara CS, Taryba M, Pinto ERP, Montemor MF. 2019. Tannin: A natural corrosion inhibitor for aluminum alloys. Progress Organic Coatings 135: 368-381. DOI:10.1016/j.porgcoat.2019.05.035

Negri G, Tabach R. 2013. Saponins, tannins and flavonols found in hydroethanolic extract from Periandra dulcis roots. Braz J Pharmacog $23 \quad$ (6): 851-860. DOI: 10.1590/S0102$695 X 2013000600001$

Oo CW, Kassim MJ, Pizzi A. 2009. Characterization and performance of Rhizophora apiculata mangrove polyflavonoid tannins in the adsorption of copper (II) and lead (II). Indust Crops Prod 30 (1): 152161. DOI: $10.1016 /$ j.indcrop.2009.03.002.

Pan F, Liu H, Guo Z, Li Z, Wang B, Cai Y, Gao A. 2019. Effects of tide and season changes on the iron-sulfur-phosphorus biogeochemistry in sediment porewater of a mangrove coast. J Hydrol 568, 686-702. DOI: $10.1016 /$ j.jhydrol.2018.11.002.

Patay ÉB, Sali N, Kőszegi T, Csepregi R, Balázs VL, Németh TS, Németh T, Papp N. 2016. Antioxidant potential, tannin and polyphenol contents of seed and pericarp of three Coffea species. Asian Pac J Trop Med 9 (4): 366-371. DOI: 10.1016/j.apjtm.2016.03.014.

Rachmatin D. 2014. Aplikasi metode-metode agglomerative dalam analisis klaster pada data tingkat polusi udara. Jurnal Ilmiah Infinity 3 (2): 133-149. DOI: 10.22460/infinity.v3i2.59. [Indonesian]

Rachmawati A. 2019. Clustering Mangrove Berdasarkan Tingkat Kerapatan di Segara Anakan Bagian Barat, Cilacap. Universitas Jenderal Soedirman, Banyumas. [Indonesian]

Rahim AA, Rocca E, Steinmetz J, Jain Kassim, M. 2008. Inhibitive action of mangrove tannins and phosphoric acid on pre-rusted steel via electrochemical methods. Corrosion Sci 50 (6): 1546-1550. DOI: 10.1016/j.corsci.2008.02.013.

Rahim AA, Rocca E, Steinmetz J, Jain Kassim M, Sani Ibrahim M, Osman H. 2008. Antioxidant activities of mangrove Rhizophora apiculata bark extracts. Food Chem 107 (1): 200-207. DOI: 10.1016/j.foodchem.2007.08.005

Ray R, Majumder N, Chowdhury C, Jana TK. 2012. Wood chemistry and density: An analog for response to the change of carbon sequestration in mangroves. Carbohydr Polym 90 (1): 102-108. DOI: 10.1016/j.carbpol.2012.05.001.

Salar R, Purewal S, Sandhu KS. 2017. Relationships between DNA damage protection activity, total phenolic content, condensed tannin content and antioxidant potential among Indian barley cultivars. Biocatal Agric Biotechnol 11: 210-206. DOI: 10.1016/j.bcab.2017.07.006

Sari LK, Adrianto L, Soewardi K, Atmadipoera AS, Hilmi E. 2016. Sedimentation in lagoon waters (Case study on Segara Anakan Lagoon). AIP Conf Proc 1730 (1): 080002. DOI: 10.1063/1.4947417

Sharma KP. 2019. Tannin degradation by phytopathogen's tannase: A plant's defense perspective. Biocatalys Agric Biotechnol 21, 101342. DOI: 10.1016/j.bcab.2019.101342.

Su L, Zhou H, Guo G, Zhao A, Zhao Y. 2012. Anaerobic biodegradation of PAH in river sediment treated with different additives. Proc Environ Sci 16, 311-319. DOI: 10.1016/j.proenv.2012.10.044.

Subandriyo, Setianingsih NI. 2016. Extraction process for reducing tannin of mangrove fruit [Bruguiera gymnorrhiza (Lamarck, 1798)] as a raw material for food flour. Aquat Proc 7, 231-235. DOI: 10.1016/j.aqpro.2016.07.032.

Suhendra, Amron , Hilmi E. 2018. The pattern of coastline change based on the characteristics of sediment and coastal slope in Pangenan coast of Cirebon, West Java. E3S Web Conf 47: 06001. DOI: 10.1051/e3sconf/20184706001.

Syakti AD, Ahmed MM, Hidayati NV, Hilmi E, Sulystyo I, Piram A, Doumenq P. 2013a. Screening of emerging pollutants in the mangrove of Segara Anakan Nature Reserve, Indonesia. IERI Proc 5, 216-222. DOI: 10.1016/j.ieri.2013.11.095

Syakti AD, Hidayati NV, Hilmi E, Piram A, Doumenq P. 2013b. Source apportionment of sedimentary hydrocarbons in the Segara Anakan 
Nature Reserve, Indonesia. Mar Pollut Bull 74 (1): 141-148. DOI: 10.1016/j.marpolbul.2013.07.015.

Tahir PM, Halip JA, Lee SH. 2019. Tannin-based bioresin as adhesives. Lignocellulose Future Bioecon 109-133. DOI: 10.1016/B978-0-12816354-2.00007-4.

Taillardat P, Ziegler AD, Friess DA, Widory D, Truong Van V, David F, Thành-Nho N, Marchand C. 2018. Carbon dynamics and inconstant porewater input in a mangrove tidal creek over contrasting seasons and tidal amplitudes. Geochim Cosmochim Acta 237, 32-48. DOI: 10.1016/j.gca.2018.06.012.

Tan KW, Kassim MJ. 2011. A correlation study on the phenolic profiles and corrosion inhibition properties of mangrove tannins (Rhizophora apiculata) as affected by extraction solvents. Corrosion Sci 53 (2): 569-574. DOI: 10.1016/j.corsci.2010.09.065.

Verheyden A, Roggeman M, Bouillon S, Elskens M, Beeckman H, Koedam N. 2005. Comparison between $\delta 13 \mathrm{C}$ of $\alpha$-cellulose and bulk wood in the mangrove tree Rhizophora mucronata: Implications for dendrochemistry. Chem Geol 219 (1-4): 275-282. DOI: 10.1016/j.chemgeo.2005.02.015.

Wang H, Gilbert JA, Zhu Y, Yang X. 2018. Salinity is a key factor driving the nitrogen cycling in the mangrove sediment. Sci Tot Environ 631: 1342-1349. DOI: 10.1016/j.scitotenv.2018.03.102.
Widowati D. 2018. Clustering Vegetasi Mangrove di Segara Anakan Bagian Timur, Cilacap. Jenderal Soedirman University, Banyumas. [Indonesian]

Willard CA. 2020. Statistical Methods (An Introduction to Basic Statistical Concepts and Analysis) (2nd Edition). Routledge, Taylor and Francis Group. DOI: 10.4324/9780429261039.

Yang Z, Song W, Zhao Y, Zhou J, Wang Z, Luo Y, Li Y, Lin G. 2018. Differential responses of litter decomposition to regional excessive nitrogen input and global warming between two mangrove species. $\begin{array}{lllll}\text { Estuar Coast Shelf Sci 214, 141-148. DOI: } & \text { D }\end{array}$ 10.1016/j.ecss.2018.09.018.

Zhang Y, Li CM. 2017. The detoxifying effects of structural elements of persimmon tannin on Chinese cobra phospholipase A2 correlated with their structural disturbing effects well. J Food Drug Anal 25 (3): 731740. DOI: $10.1016 /$ j.jfda.2016.08.005.

Zhou HC, Tam NFY, Lin YM, Wei SD, Li YY. 2012. Changes of condensed tannins during decomposition of leaves of Kandelia obovata in a subtropical mangrove swamp in China. Soil Biol Biochem 44 (1): 113-121. DOI: 10.1016/j.soilbio.2011.09.015. 